\title{
The Tourism Student Social Status: The Role Nature of Work and Career Prospect
}

\author{
Janfry Sihite $^{1} \quad$ Triana Rosalina Dewi $^{2} \quad$ Novita Widyastuti $^{2 *}$ \\ 1.Department of Management, Universitas Mercu Buana, Indonesia \\ 2.Department of Hospitality, STP Trisakti, Indonesia
}

\begin{abstract}
The research investigates the career prospects and the nature of work of the college student in the tourism industry toward social status. The research sample is the student of Trisakti Tourism School Indonesia, and there are a total of 74 respondents collected, which further analyzed using the SmartPLS. The research finding shows that the Career Prospect and the Nature of Work influence Social Status. The Career Prospect has more significant influence compare with the Nature of Works. This research show that the Career Prospect related to the Social Status and the findings show that the respondent is feeling confident and proud of their career in the tourism industry.
\end{abstract}

Keywords: Social Status, Nature of Work, Career Prospect, Tourism, STP Trisakti

DOI: $10.7176 / \mathrm{EJBM} / 11-23-13$

Publication date: August $31^{\text {st }} 2019$

\section{Research Background}

The growing hotel and tourism industry need the support of qualified labor. There is a demand for new labor and also to retain the existing labor (Wan, Wong \& Kong, 2014). The industry should manage the supply of the human resources; therefore they could nurture a qualified labor (Richardson, 2010).

To improve the number of the human resources, and attracted the youth to work in the industry; therefore the industry should manage the excellent perception and also the wrong or negative perception regards to the industry. Some negative perception like a 24 hour working hour, shiftwork, working until midnight, working in the holiday, the perception of the no compensation, influence the prospective student and also the parents toward the future career. Furthermore, when they are at the junior level, they will work all day long; therefore many of them are quitting and makes the turnover in the tourism industry high (Roney \& Oztin, 2007).

The demand of the hotel and tourism industry human resources related to the millennial. They are different from the previous generation X, since they are living in the Internet world. They are delivering content from and to social media. Therefore all of this status can be seen by their surrounding, friends, and family. Moreover, it makes the social status is essential to the millennials.

Researcher and also the industry in the tourism need to engage and retain the qualified staff. To be able to do this, the tourism industry stakeholder needs to explore and to find out the relationship of the social status, influence the prospect of the career in the tourism industry and also how it relate with the nature of work in the tourism and hotel industry.

The industry needs to know this perception, and insight is essential for managing the existing labor. The hotel and tourism industry also needs to know this perception to be able to influence the performance of the staff and develop the competitiveness of the services. This is necessary since the staff in the hotel and tourism industry are delivering services face to face with the customer, and also have to solve the problems directly with the customer. If the staff have some negative perception powered the prospect career, therefore they will not go to be able to focus on delivering an excellent service. They are not going to be motivated to perform the best and delivering an excellent service.

Furthermore, if the staff have a good perception toward to industry, they will tend to give excellent services and a better performance, which will make the consumer satisfied for the services they received (Zeithaml, Bitner, Gremler, \& Pandit, 2006). A good motivation will also decrease the turnover of the human resource in the hotel and tourism industry (Aycan \& Fikret-Pasa, 2003).

If the student knows their career prospects, they will focus on learning how to give an excellent service, and it will influence their motivation to develop him or herself to suit in the industry. The education sector also needs this research since they will have to prepare a curriculum that is available to develop the quality of human resources. Proposing an excellent working field that's what the human resources and make sure there is a relevant process to develop the human resources needed (Aycan \& Fikret-Pasa, 2003).

There is research about the perception of the student for the tourism industry. An exploratory research of the student behavior will show the student perception toward the hotel and tourism industry. There is also research that predicts the intention of the student over the industry after they graduated (Paul \& Gill, 1993).

Another focus on the research in term of the career prospect of the student is related to some variables. How the working experience, length of study, influence of social network related to the behavior of the human resource 
and also the intention toward career and commitment in the industry (Paul \& Gill, 1993). If the working experience is needed, therefore, they will prepare to have an internship, if the social networks highly related to the student, therefore, they will consider the social networks recommendation toward career prospects. Many variables will influence the performance, the intention of the student toward the tourism industry.

It is essential to find out factors that influence student social status. How the student's career prospects will influence the social status and how the nature of work also influence social status. The research will investigate the student perspective towards the social status of working in the hotel and tourism industry. The research is merely relevant since the millennial considers social status as one of the needs that fulfilled. They are merely connecting with social media and promoting their social status, showing to the social networks their activities. Therefore their occupation social status, their nature of work, and the social network perspective towards the career is essential for the millennials.

\section{Theoretical Review}

The psychological contract theory state that someone should convince him or herself for the consequences and the responsibility for the occasion. Since working in the tourism industry requires a long time of working hours; therefore they are not going to be interested (Kelley \& George, 2001).

The real condition of an occupation relates to the career prospect. Therefore the real condition is in line with the incentive, the future career prospects and also the first opportunities for a better career compare with the other occupation (Richardson, 2008).

The career prospect is one of the attributes that influence the perception and hope for revenue to work in the selected industry (Kusluvan \& Kusluvan, 2000). It means that if there is an excellent opportunity ahead, therefore the career prospect will be useful, and it will influence a good perception toward the occupation.

Social status is part of the social system, it relates with the environment, and it could defined as the community perception toward the individual (Vecchio, Hearn \& Southey, 1992). For the millennial, social status is the perception of the community and also within the social media. Social status also could be related with an occupation, the responsibility, the personal characteristic, and how do people behave toward the social status or within the community (Parcel \& Mueller, 1983).

There is also disadvantages of the occupation in tourism in the hotel industry. Research in Ireland show that the length of time of working hours, make the individual intention to work to the industry are low, and the job is not challenging that made the alumni have lower perception toward career development and the future career path. From this argument, $\mathrm{H} 1$ developed, the nature of work related to the career prospect.

Social status is a unit of the social system, the social status related to the environment, how the environment or the community perception toward the individual (Vecchio, Hearn, \& Southey, 1992). For the millennials, social status related to the perception of the community which are their family, their friends and also the perception developed in the social media from the information that they deliver relate to the activities or any information related to him or herself. In term of the social status related to the occupation, the social status relates to the responsibility, the personal characteristics of the worker, and how the people behave within the community (Parcel \& Mueller, 1983).

Social status definition could be evaluated whether the individual has the self-confidence, are they proud of the career that they have (Kusluvan \& Kusluvan, 2000). How the member of the family proud of the occupation of the individual, and how the profession perception being respected and considered as an important job within the community.

Some research found that the occupation and social status relevancy is necessary. If the occupation respected by the community, the student who work will be respected. Furthermore, the student will earn the confidence and motivated to pursue a career in the industry.

In Indonesia, occupation in the hotel and tourism industry have an unfavorable perception. It is because of the working hour until late at night, and they also work when it is a holiday. The occupation is different with the other occupation, like the civil servant, they are considered an excellent occupation since they got the salary from the government, the pension, and they did not work late at night.

Research conducted for the tourism program in New Zealand found that the alumni consider that the nature of work in the hotel industry is an important attribute. An exciting and challenging occupation in the hotel could mitigate the disadvantage relate to the negative status and the industry image. (Kusluvan \& Kusluvan, 2000) stated that the tourism student perception toward the tourism environment in turkey, correlated significantly towards the social status.

Therefore we could develop a hypothesis that the nature of work and career prospect related to the social status of the students in the tourism and hotel industry (H2 \& H3). The research model proposed as in figure 1. 


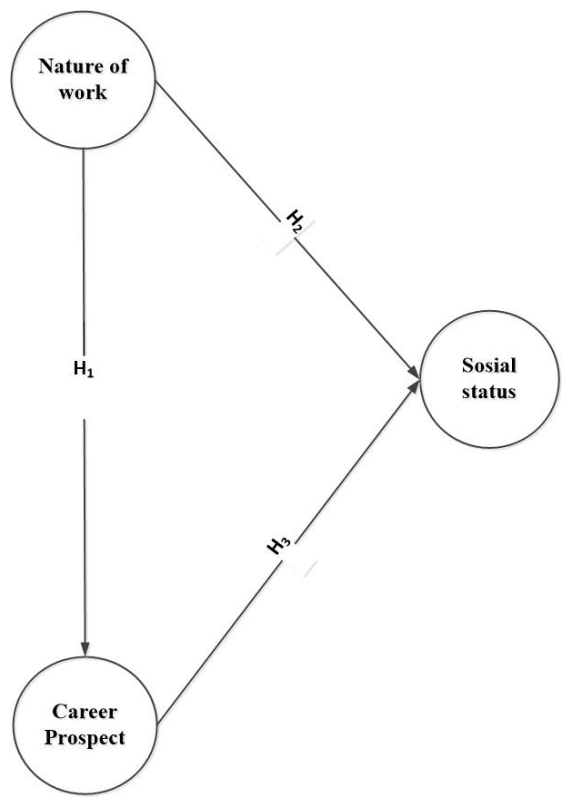

Figure 1. Research model

\section{Research Method}

The questionnaire delivered to the target respondent at STP Trisakti (Table 1). Respondent eligible to answer the question is respondent that experiencing an internship in tourism in the hotel industry. STP Trisakti selected since the school is a well-known tourism and hospitality in Indonesia. Therefore, they are a charitable institution to develop the human resource in Indonesia.

Structural equation modeling selected as a statistical model to explain the relationship between variables within the model. The structure of association analyzes for the entire relationship between the construction, which consist of the independent and dependent variable (Hair, Hult, Ringle, Sarstedt, 2013). Structural equation modeling used in this research is the PLS. PLS could estimate a large and complex model and also confirming the variables within a theory (Falk \& Miller, 1992).

PLS is useful and powerful as a tool of analysis since it could improve the resampling technique with the bootstrap (Stine, 1989), (Sihite, Harun, Nugroho, 2015). Therefore we could get a meaningful interpretation of regression coefficients (Darlington, 1990). The regression analysis in the study will analyze the dependent $Y$ variables as a result of the Independent $X$ predictor (Hayes, 2013).

Table 1. Questionnaire Development

\begin{tabular}{|l|l|}
\hline Nature of Work \\
\hline NW1 & the work in the hotel industry is interesting \\
\hline NW7 & there are always new things that the student experience when they have the internship \\
\hline NW10 & the work in the hotel industry is challenging \\
\hline NW12 & seeing new people in the internship is an exciting experience \\
\hline Career Prospect \\
\hline CP1 & the opportunity for promotion in the hotel industry are satisfying \\
\hline CP2 & learning in the school of tourism are a good investment in developing the career \\
\hline CP3 & the earnings in the hotel industry are good \\
\hline Cp4 & the earnings in the hotel industry are more significant compared with the other industry \\
\hline CP10 & $\begin{array}{l}\text { generally, the benefit of working in the hotel industry is more significant compared with the } \\
\text { disadvantages }\end{array}$ \\
\hline Social Status & \multicolumn{2}{|l|}{} \\
\hline SS1 & The family are proud of his or her work plan \\
\hline SS2 & working in the hotel industry is an essential occupation in the community \\
\hline SS5 & I am proud of my career plans \\
\hline
\end{tabular}

\section{Results and Discussion}

The research measured the career prospects, and the nature of work influence towards the social status. Total 74 respondents analyzed for further analysis from 100 collected questionnaire. 
The career prospects and the nature of work influence the students social status. Furthermore, the career prospects have a bigger influence compare with the nature of work. The nature of work has the most significant influence on the career prospect. The findings show that there is a strong relationship between the nature of work and also the career prospects (Figure 2).

The nature of work variable consists of four indicators, the question relates to the statement that the hotel industry is attractive, there are always new experience by the student when they have the internship, the statement related to the challenging aspect of working in the hotel industry, and statement related to seeing new people as an exciting experience. Two of the indicators of nature of work have the highest score, which is the statement that the hotel industry is changing and they are seeing new people in the internship. It means that both of these indicators have the highest preference for the respondent.

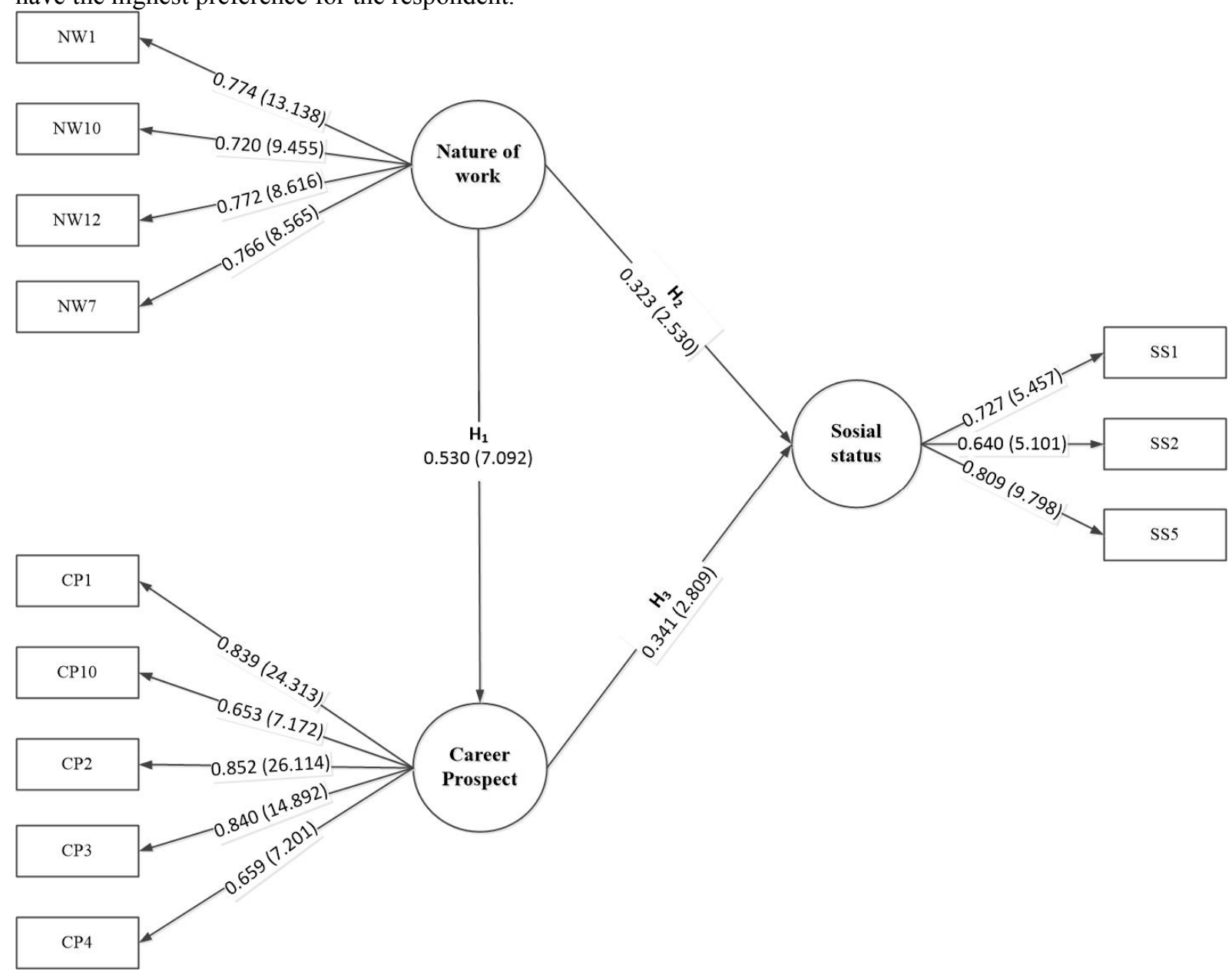

Figure 2. Nature of Work, Social Status and Career Prospect

There are also five indicators for the career prospect. There is a statement related to the opportunity for promotion in the hotel industry are satisfying, It is an excellent investment to develop the career in the tourism, and a statement relating to the good earnings in the hotel industry compare to the other industry, and the last is the indicator that state the benefit for working in the hotel industry are bigger compare with the disadvantages. The highest rank of indicators are related to the statement that studying in the hotel and tourism school is a good investment to develop a career. This finding convinced that studying in tourism is an excellent investment for the student

future. 
Table 2. Mean, STDEV, T-Values, P-Values

\begin{tabular}{|l|l|l|l|l|l|}
\hline & $\begin{array}{l}\text { Original } \\
\text { Sample (O) }\end{array}$ & $\begin{array}{l}\text { Sample } \\
\text { Mean (M) }\end{array}$ & $\begin{array}{l}\text { Standard } \\
\text { Deviation } \\
\text { (STDEV) }\end{array}$ & $\begin{array}{l}\text { T Statistics } \\
(\mid \mathbf{O} / \text { STDEV } \mid)\end{array}$ & P Values \\
\hline CP1 <- Career Prospect & 0.839 & 0.836 & 0.035 & 24.313 & $\mathbf{0 . 0 0 0}$ \\
\hline CP10 <- Career Prospect & 0.653 & 0.648 & 0.091 & 7.172 & $\mathbf{0 . 0 0 0}$ \\
\hline CP2 <- Career Prospect & 0.852 & 0.850 & 0.033 & 26.114 & $\mathbf{0 . 0 0 0}$ \\
\hline CP3 <- Career Prospect & 0.840 & 0.839 & 0.056 & 14.892 & $\mathbf{0 . 0 0 0}$ \\
\hline CP4 <- Career Prospect & 0.659 & 0.655 & 0.091 & 7.201 & $\mathbf{0 . 0 0 0}$ \\
\hline NW1 <- Nature of Work & 0.774 & 0.771 & 0.059 & 13.138 & $\mathbf{0 . 0 0 0}$ \\
\hline NW10 <- Nature of Work & 0.720 & 0.720 & 0.076 & 9.455 & $\mathbf{0 . 0 0 0}$ \\
\hline NW12 <- Nature of Work & 0.772 & 0.758 & 0.090 & 8.616 & $\mathbf{0 . 0 0 0}$ \\
\hline NW7 <- Nature of Work & 0.766 & 0.753 & 0.089 & 8.565 & $\mathbf{0 . 0 0 0}$ \\
\hline SS1 <- Social Status & 0.727 & 0.701 & 0.133 & 5.457 & $\mathbf{0 . 0 0 0}$ \\
\hline SS2 <- Social Status & 0.640 & 0.637 & 0.125 & 5.101 & $\mathbf{0 . 0 0 0}$ \\
\hline SS5 <- Social Status & 0.809 & 0.794 & 0.083 & 9.798 & $\mathbf{0 . 0 0 0}$ \\
\hline
\end{tabular}

The last variable consists of 3 indicators which are the statement that the family is proud for their work, the statement that said working in the hotel industry is an important occupation and recognized in the community, and the last indicator is the statement that the career plans in the tourism industry are improving. The highest score for the indicator is the statement that they are proud of the future career plans (Table 2). This finding shows that they are confident in the future career prospects in the hotel industry, and this is a good side of the hotel and tourism industry. This good perception will need to be improved, and more students will be enrolled and study in the tourism and hospitality school.

Table 3. Total Indirect Effects

\begin{tabular}{|l|l|l|l|}
\hline Total Indirect Effects & & & \\
\hline & Nature of Work & Career Prospect & Social Status \\
\hline Nature of Work & & & 0.184 \\
\hline Career Prospect & & & \\
\hline Social Status & & & \\
\hline
\end{tabular}

Table 4. Specific Indirect Effects

\begin{tabular}{|l|l|}
\hline Specific Indirect Effects & \\
\hline & Specific Indirect Effects \\
\hline Nature of Work -> Career Prospect & 0.184 \\
\hline
\end{tabular}

The Indirect effects and specific indirect effect show a consistent value 0f 0.184 (Table $3 \&$ Table 4). The value shows that there is an effect of nature of work toward the social status via the career prospect. Therefore it is the only indirect effect exist in the model.

Table 5. Total Effects

\begin{tabular}{|l|l|l|l|}
\hline Total Effects & & & \\
\hline & Nature of Work & Career Prospect & Social Status \\
\hline Nature of Work & & 0.546 & 0.518 \\
\hline Career Prospect & & & 0.339 \\
\hline Social Status & & & \\
\hline
\end{tabular}

The total findings show that nature of work influence the career prospect and social status bigger compare with the career prospect toward the social status (Table 5). Therefore the nature of work has a dominant positioned compare to the other variable in the model.

These findings relate to the nature of the work variable; there is a statement that the occupation in the hotel industry is fascinating. Therefore this is in line with the characteristic of the respondent that have the internship in the hotel industry. The internship experience makes them confidence that the investment for studying in the hotel and tourism school is the right decision. Overall the respondent characteristic in the research shows that they have self-confidence, their career exciting and they are in an exciting industry which they are proud of for their plans.

\section{Conclusion}

The research shows that the students have the self-confidence for the tourism industry, and this is a good capital to improve the good perception for the tourism industry. There is also a relationship in term of the career prospects and the social status; the career prospect is highly relevant with the nature of work, which means they are optimist that the career prospects will be good in the future.

The research findings show that there is a need to expose a newness of seeing people in the tourism industry. 
Therefore to promote these occasion, the university needs to promote the openness of seeing new people and also the potential revenue for the student that is working in the hotel industry, both of these factors will influence the student interest to enroll in the tourism and hotel school.

Recommendation for the university is to promote the hotel and tourism industry as an exciting and enjoyable occupation for the future. The industry will need a hard worker employee since this is the nature of the work in the tourism industry, but they have to improve the social status of the students to work in the hotel and tourism industry.

\section{References}

Aycan, Z., \& Fikret-Pasa, S. (2003). Career choices, job selection criteria, and leadership preferences in a transitional nation: The case of Turkey. Journal of Career Development, 30(2), 129-144.

Baum, T. (2006). Human resource management for tourism, hospitality and leisure: An international perspective: Cengage Learning EMEA.

Darlington, R. B. (1990). Regression and linear models: McGraw-Hill New York.

Falk, R. F., \& Miller, N. B. (1992). A primer for soft modeling: University of Akron Press.

Hair, J. F., Hult, G. T. M., Ringle, C. M., \& Sarstedt, M. (2013). A primer on partial least squares structural equation modeling (PLS-SEM): Sage Publications.

Hayes, A. F. (2013). Introduction to mediation, moderation, and conditional process analysis: A regression-based approach: Guilford Press.

Kelley-Patterson, D., \& George, C. (2001). Securing graduate commitment: an exploration of the comparative expectations of placement students, graduate recruits and human resource managers within the hospitality, leisure and tourism industries. International Journal of Hospitality Management, 20(4), 311-323.

Kusluvan, S., \& Kusluvan, Z. (2000). Perceptions and attitudes of undergraduate tourism students towards working in the tourism industry in Turkey. Tourism Management, 21(3), 251-269.

Parcel, T. L., \& Mueller, C. W. (1983). Occupational differentiation, prestige, and socioeconomic status. Work and Occupations, $10(1), 49-80$.

Paul, B., \& Gill, M. (1993). Hospitality Management Students' Image of the HospitalityIndustry. International Journal of Contemporary Hospitality Management, 5(5).

Richardson, S. (2008). Undergraduate tourism and hospitality students attitudes toward a career in the industry: A preliminary investigation. Journal of Teaching in Travel \& Tourism, 8(1), 23-46.

Richardson, S. (2010). Generation Y's perceptions and attitudes towards a career in tourism and hospitality. Journal of Human Resources in Hospitality \& Tourism, 9(2), 179-199.

Roney, S. A., \& Oztin, P. (2007). Career perceptions of undergraduate tourism students: A case study in Turkey. Journal of Hospitality, Leisure, Sport and Tourism Education, 6(1), 4-17.

Sihite, J., Harun, T. W., \& Nugroho, A. (2015). The Low Cost Airline Consumer Price Sensitivity. An Investigation on The Mediating Role of Promotion and Trust in Brand. International Research Journal of Business Studies, $\operatorname{VII}(3)$.

Stine, R. (1989). An introduction to bootstrap methods examples and ideas. Sociological Methods \& Research, 18(2-3), 243-291.

Vecchio, R. P., Hearn, G., \& Southey, G. (1992). Organisational behaviour: Life at work in Australia: Harcourt Brace Jovanovich.

Wan, Y. K. P., Wong, I. A., \& Kong, W. H. (2014). Student career prospect and industry commitment: The roles of industry attitude, perceived social status, and salary expectations. Tourism Management, 40, 1-14.

Zeithaml, V. A., Bitner, M. J., Gremler, D. D., \& Pandit, A. (2006). Services marketing: Integrating customer focus across the firm. 